\title{
SwrAA activates poly- $\gamma$-glutamate synthesis in addition to swarming in Bacillus subtilis
}

\author{
Cecilia Osera, Giuseppe Amati, Cinzia Calvio and Alessandro Galizzi
}

\section{Correspondence \\ Cinzia Calvio \\ cinzia.calvio@unipv.it}

Received 5 December 2008

Revised 3 March 2009

Accepted 2 April 2009

\author{
Dipartimento di Genetica e Microbiologia, Università degli Studi di Pavia, via Ferrata 1, 27100 Pavia, \\ Italy
}

\begin{abstract}
Poly- $\gamma$-glutamic acid ( $\gamma$-PGA) is an extracellular polymer produced by various strains of Bacillus. It was first described as the component of the capsule in Bacillus anthracis, where it plays a relevant role in virulence. $\gamma$-PGA is also a distinctive component of 'natto', a traditional Japanese food consisting of soybean fermented by Bacillus subtilis (natto). Domesticated B. subtilis strains do not synthesize $\gamma$-PGA although they possess the functional biosynthetic pgs operon. In the present work we explore the correlation between the genetic determinants, swrAA and $\operatorname{deg} U$, which allow a derivative of the domestic strain JH642 to display a mucoid colony morphology on LB agar plates due to the production of $\gamma$-PGA. Full activation of the pgs operon requires the copresence of SwrAA and the phosphorylated form of DegU (DegU P). The presence of either DegU P or SwrAA alone has only marginal effects on pgs operon transcription and $\gamma$-PGA production. Although SwrAA was identified as necessary for swarming and full swimming motility together with DegU, we show that motility is not involved in $\gamma$-PGA production. Activation of $\gamma$-PGA synthesis is therefore a motility-independent phenotype in which SwrAA and DegU P display a cooperative effect.
\end{abstract}

\section{INTRODUCTION}

Poly- $\gamma$-glutamic acid ( $\gamma$-PGA) is an anionic polymer of increasing industrial interest composed of thousands of glutamic acid residues (1200-12000) linked by $\gamma$-glutamyl bonds (Shih \& Van, 2001; Candela \& Fouet, 2006). In Bacillus subtilis its synthesis is carried out by the pgs operon containing the genes $p g s B, p g s C$, $p g s A A$ and $p g s E$ (formerly $y w s C, y w t A, B, C)$. In contrast to wild strains, most laboratory strains of $B$. subtilis do not produce $\gamma$-PGA because the $p g s$ operon is not transcribed (Urushibata et al., 2002). In a search for the genetic determinants that control the formation of the exopolymeric matrix in which $B$. subtilis biofilms are encased, Stanley \& Lazazzera (2005) identified $\operatorname{deg} Q$ and $s w r A A$ as the genes responsible for $\gamma$ PGA production, allowing a non-producer laboratory strain to be converted into a mucoid $\gamma$-PGA producer by simply introducing the $\operatorname{deg} Q_{\mathrm{H}}(\operatorname{sacQ36}$, Yang et al., 1986) and swrAA ${ }^{+}$alleles (Kearns et al., 2004; Calvio et al., 2005). The $\operatorname{deg} Q_{\mathrm{H}}$ mutation is a single base substitution in the $\operatorname{deg} Q$ promoter enhancing its expression (Yang et al., 1986). DegQ facilitates phosphate transfer from the DegS kinase to its cognate response regulator DegU (Kobayashi, 2007) and strains carrying the $\operatorname{deg} Q_{\mathrm{H}}$ mutation have the same phenotype as $\operatorname{deg} U(\mathrm{Hy})$ and $\operatorname{deg} S(\mathrm{Hy})$ mutant strains (Amory et al., 1987; Msadek et al., 1990), with the latter mutations reducing the dephosphorylation rate of DegU

Abbreviations: $\gamma$-PGA, poly- $\gamma$-glutamic acid; DegU P, phosphorylated DegU; wt, wild-type.
(Tanaka et al., 1991; Dahl et al., 1992) and resulting in an overall high level of phosphorylated $\operatorname{DegU}(\operatorname{DegU} \sim \mathrm{P}$ ). SwrAA is a small protein (117 amino acids) without any recognizable structural motif from which a molecular role can be inferred. Laboratory strains carry a single nucleotide insertion in the coding region of swrAA leading to premature product truncation $\left(s w r A A^{-}\right)$(Kearns et al., 2004). In a laboratory strain, complementation experiments with a wild-type (wt) copy of the gene resulted in a significant improvement in both swimming capacity and ability to swarm on semi-solid surfaces treated with surfactin (Calvio et al., 2005, 2008), biasing cells into a $\sigma^{\mathrm{D}}$-ON state (Kearns \& Losick, 2005). The swrAA $A^{-}$motility phenotype could be suppressed by a fla/che promoter upmutation, and microarray experiments indicated that SwrAA enhances expression of the fla/che operon, acting on the $\sigma^{\mathrm{A}}$-dependent promoter $\mathrm{P}_{\text {fla }}$ /che(A) (Kearns \& Losick, 2005). Several lines of evidence point to a cooperation between SwrAA and DegU P in motility (Kobayashi, 2007; Verhamme et al., 2007; Calvio et al., 2008) and here we demonstrate not only that the two proteins must cooperate to drive $\gamma$-PGA production, but also that such an effect is achieved independently of the activation of the fla/che promoter.

\section{METHODS}

Bacterial strains and growth conditions. B. subtilis and Escherichia coli strains were grown in Luria-Bertani (LB) broth at $37{ }^{\circ} \mathrm{C}$. LB 
broth contained $1 \%$ tryptone (Difco), $1 \% \mathrm{NaCl}$ and $0.5 \%$ yeast extract (Difco). LB plates were prepared by the addition of $1.5 \%$ $(\mathrm{w} / \mathrm{v})$ agar. Where appropriate, antibiotics were added at the following concentrations: $60 \mu \mathrm{g}$ spectinomycin $\mathrm{ml}^{-1}, 1 \mu \mathrm{g}$ erythromycin $\mathrm{ml}^{-1}, 2 \mu \mathrm{g}$ kanamycin $\mathrm{ml}^{-1}, 5 \mu \mathrm{g}$ phleomycin $\mathrm{ml}^{-1}$.

Strain construction. Bacterial strains and primers used in this study are listed in Tables 1 and 2, respectively. Our swrAA ${ }^{+}$PB5249 strain is a spontaneous derivative of JH642 (Calvio et al., 2005), while PB5370 is a marker-less strain derived from PB5249 carrying the swrAA- gene (Calvio et al., 2008).

To construct strains with $\operatorname{degU} 32(\mathrm{Hy})$ or $\operatorname{degS200}(\mathrm{Hy})$ mutations, the $\operatorname{degS}-\operatorname{deg} U$ region was amplified with primers loxdegS1 and loxdegU1 from PB5213 and PB5246 chromosomal DNA (Amati et al., 2004) as templates. The products were cloned into the XhoI and HindIII sites of plasmid pLoxSpec (a generous gift from E. Ferrari, Genencor, Palo Alto, CA, USA), thus generating pLoxdegS1 U(Hy) or pLoxdegS200$\mathrm{U} 1$. The region upstream of $\operatorname{degS}-\operatorname{deg} U$ was amplified from PB5249 chromosomal DNA by using primers loxdegS2 and loxdegS3 and the PCR product was cloned into the corresponding site of pLoxdegS1 U(Hy) or pLoxdegS200-U1 after NotI digestion. The resulting recombinant plasmids pLoxSpec/degSU(Hy) and pLoxSpec/ degS200 contain the spectinomycin resistance gene flanked by the region upstream of the $\operatorname{deg} S-\operatorname{deg} U$ locus and by the $\operatorname{deg} S-\operatorname{deg} U$ locus itself carrying either the $\operatorname{deg} U 32(\mathrm{Hy})$ or $\operatorname{degS200}(\mathrm{Hy})$ mutations. The recombinant plasmids, linearized with $N c o I$ and $A h d \mathrm{I}$, were transformed into strain PB5249 or PB5370. Since the resistance marker is distant from both mutations, spectinomycin-resistant transformants did or did not incorporate the desired mutations depending on the position of the recombination event. The presence of the $\operatorname{deg} U 32(\mathrm{Hy})$ and $\operatorname{degS200}(\mathrm{Hy})$ mutations was checked by digestion with Eco571 and EcoRI, respectively. Strains PB5381 (degU/ $\left.S^{+}{ }{ }_{w r A A^{+}}\right), \operatorname{PB} 5382\left(\operatorname{deg} U / S^{+} \quad s w r A A^{-}\right)$, PB5383 [degU32(Hy) swrAA $A^{+}$], PB5384 [degU32(Hy) swrAA $A^{-}$], PB5390 [degS200(Hy) swrAA ${ }^{+}$] and PB5391 [degS200(Hy) swrAA ${ }^{-}$] were thus constructed.

For the construction of the $p g s B$-lac $Z$ transcriptional fusions, PB5249 and PB5370 were transformed with chromosomal DNA extracted from the pgsB::pMUTIN4 strain BFS1235 (Schumann et al., 2001), selecting for erythromycin resistance. The resulting derivatives, in which the $p g s$ locus is inactivated by pMUTIN4 insertion, were in turn transformed using PB5381-84 chromosomal DNAs as donor and selected for spectinomycin resistance to give rise to strains PB541619. The incorporation of the $\operatorname{deg} U 32$ (Hy) mutation was checked by digestion with Eco571.

For the construction of strain PB5422, PB5249 was co-transformed with PB5383 and PB5129 DNAs. Transformants were selected for resistance to kanamycin and spectinomycin and checked for the conservation of the swrAA ${ }^{+}$marker. For the construction of $\operatorname{deg} U 32(\mathrm{Hy})$ strains carrying the mutant swrA promoters, strains PB5393, PB5394 and PB5395 (Calvio et al., 2008) were transformed with pLoxSpec/degSU(Hy), producing strains PB5438, PB5439 and PB5440, respectively.

To introduce the dhsA6 mutation (Amati et al., 2004) into PB5249 and PB5370, the shuttle vector pMAD (Arnaud et al., 2004) was used. A PCR fragment was amplified from PB5319 (Amati et al., 2004) using primers codYF and nRflgBN, digested with EcoRI and $\mathrm{NcoI}$ and inserted between the corresponding sites of pMAD. The resulting plasmid pMADdhs was used to transform PB5370 following the procedure described by Arnaud et al. (2004). The incorporation of the $d h s A 6$ mutation was checked by sequencing. The resulting strain was transformed with pLoxSpec/degSU(Hy),

Table 1. Strains used in this study

\begin{tabular}{|c|c|c|}
\hline \multicolumn{3}{|l|}{ E. coli } \\
\hline $\mathrm{DH} 5 \alpha$ & supE44 lacU169 [ $\phi 80$ lacZLM15] $\left.h s d R 17 \mathrm{r}_{\mathrm{K}}^{-} \mathrm{m}_{\mathrm{K}}^{+}\right]$recA1 endA1 gyrA96 thi-1 relA1 & Lab strain \\
\hline BFS1235 & $\operatorname{trp} C 2 \operatorname{pgs} B::$ pMUTIN4 $\left(\mathrm{Em}^{\mathrm{r}}\right)$ & Schumann et al. (2001) \\
\hline PB5129 & $\operatorname{trp} C 2 \Delta$ flaA:: $k a n\left(\mathrm{Km}^{\mathrm{r}}\right)$ & Barilla et al. (1994) \\
\hline PB5249 & $\operatorname{trpC2}$ pheA1 swrAA ${ }^{+}$ & Calvio et al. (2005) \\
\hline PB5370 & $\operatorname{trp} C 2$ pheA1 swrAA $A^{-}$ & Calvio et al. (2008) \\
\hline PB5381 & $\operatorname{trpC2}$ pheA1 swrAA ${ }^{+}\left(\mathrm{Sm}^{\mathrm{r}}\right)$ & This study \\
\hline PB5382 & $\operatorname{trpC2}$ pheA1 swrAA $\left(\mathrm{Sm}^{\mathrm{r}}\right)$ & This study \\
\hline PB5383 & $\operatorname{trpC2}$ pheA1 swrAA ${ }^{+} \operatorname{degU} 32(\mathrm{Hy})\left(\mathrm{Sm}^{\mathrm{r}}\right)$ & This study \\
\hline PB5384 & $\operatorname{trpC2}$ pheA1 swrAA ${ }^{-} \operatorname{deg} U 32(\mathrm{Hy})\left(\mathrm{Sm}^{\mathrm{r}}\right)$ & This study \\
\hline PB5417 & $\operatorname{trp} C 2$ pheA1 swrAA $A^{-}$pgsB::pMUTIN4 $\left(\mathrm{Em}^{\mathrm{r}}\right)\left(\mathrm{Sm}^{\mathrm{r}}\right)$ & This study \\
\hline PB5418 & $\operatorname{trpC} 2$ pheA1 swrAA ${ }^{+} \operatorname{degU} 32(\mathrm{Hy})$ pgsB::pMUTIN4 $\left(\right.$ Ery $\left.^{\mathrm{r}}\right)\left(\mathrm{Sm}^{\mathrm{r}}\right)$ & This study \\
\hline PB5419 & $\operatorname{trp} C 2$ pheA1 swrAA ${ }^{-} \operatorname{degU32}(\mathrm{Hy})$ pgsB::pMUTIN4 $\left(\right.$ Ery $\left.^{\mathrm{r}}\right)\left(\mathrm{Sm}^{\mathrm{r}}\right)$ & This study \\
\hline PB5422 & $\operatorname{trpC2}$ pheA1 swrAA ${ }^{+} \operatorname{deg} U 32(\mathrm{Hy}) \Delta$ flaA:: $\operatorname{kan}\left(\mathrm{Km}^{\mathrm{r}}\right)\left(\mathrm{Sm}^{\mathrm{r}}\right)$ & This study \\
\hline PB5429 & $\operatorname{trpC2}$ pheA1 swrAA ${ }^{+} \operatorname{degU32(\mathrm {Hy})}$ pks:: $\mathrm{P}_{s w r A} \mathrm{WT}-\operatorname{lacZ} \Delta \operatorname{sig} D\left(\mathrm{Sm}^{\mathrm{r}}\right)\left(\mathrm{Km}^{\mathrm{r}}\right)\left(\mathrm{Em}^{\mathrm{r}}\right)$ & Calvio et al. (2008) \\
\hline PB5438 & $\operatorname{trp} C 2$ pheA1 $\mathrm{P}_{\text {swrA }} \mathrm{A}^{-}$-swrAA $A^{+} \operatorname{degU32}(\mathrm{Hy})\left(\mathrm{Km}^{\mathrm{r}}\right)\left(\mathrm{Sm}^{\mathrm{r}}\right)$ & This study \\
\hline PB5439 & $\operatorname{trpC} 2$ pheA1 $\mathrm{P}_{\text {swrA }} \mathrm{D}^{-}-$swrAA $A^{+} \operatorname{deg} U 32(\mathrm{Hy})\left(\mathrm{Km}^{\mathrm{r}}\right)\left(\mathrm{Sm}^{\mathrm{r}}\right)$ & This study \\
\hline PB5440 & $\operatorname{trpC} 2$ pheA1 $\mathrm{P}_{\text {swrA }} \mathrm{DA}^{-}-s w r A A^{+} \operatorname{degU32}(\mathrm{Hy})\left(\mathrm{Km}^{\mathrm{r}}\right)\left(\mathrm{Sm}^{\mathrm{r}}\right)$ & This study \\
\hline PB5447 & $\operatorname{trpC2}$ pheA1 swrAA $A^{-}$dhsA6 $\operatorname{deg} U 32(\mathrm{Hy})\left(\mathrm{Sm}^{\mathrm{r}}\right)$ & This study \\
\hline
\end{tabular}


Table 2. Oligonucleotide primers used in this study

\begin{tabular}{|c|c|}
\hline Primer & Sequence (restriction sites are underlined) \\
\hline BL468 & 5'-CGAAGACGTTGTCCGATATTAAAAG-3' \\
\hline BL469 & 5'-CAACAGTCTCAGTCAAAATATCAGC-3' \\
\hline BL517 & 5'-CTGTTAACCCAGATTATCAAATC-3' \\
\hline BL518 & 5' -CTGCGCGGCAGTTCATGATGAT-3' \\
\hline loxdegS1 & 5'-CCGCTCGAGATAAAAGACTGCCTATACAAATTCG-3' \\
\hline loxdegS2 & 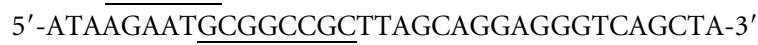 \\
\hline $\operatorname{loxdegS3}$ & 5'-ATAAGAATGCGGCCGCTTCCGTTCTACAACACCTA-3' \\
\hline loxdegU1 & 5'-CCCAAGCTTGTCTGCAAGCATCTGCAGCACTTCAC-3' \\
\hline codYF & 5'-CGGAATTCTAGTGAATATACTGCTTTCCC-3' \\
\hline nRflgBN & 5'-GCCCATGGTTATAGTTCGGTGTATCTATATTG-3' \\
\hline
\end{tabular}

producing PB5447. Recombinant plasmids and chromosomal mutations were sequenced.

$\boldsymbol{\beta}$-Galactosidase assay. To assay $\beta$-galactosidase activity, overnight cultures grown in Antibiotic Medium 3 (Difco) containing $0.5 \%$ glucose were diluted in fresh $\mathrm{LB}$ medium to an $\mathrm{OD}_{600}$ of 0.2 . Cells were grown at $37^{\circ} \mathrm{C}$ with shaking and samples $(1 \mathrm{ml})$ were taken at $30 \mathrm{~min}$ intervals for $\mathrm{OD}_{600}$ readings. Cell pellets were resuspended in $1 \mathrm{ml} \mathrm{Z}$ buffer (Miller, 1972) containing $100 \mu \mathrm{g}$ lysozyme and $10 \mu \mathrm{g}$ DNase I and lysed by 20 min incubation at $37^{\circ} \mathrm{C}$. $\beta$-Galactosidase activity was calculated as described by Miller (1972) according to the formula $\left(A_{420} \times 1.5\right) /\left(\mathrm{OD}_{600} \times\right.$ sample volume in $\mathrm{ml} \times$ reaction time in $\min \times 0.00486)$. Experiments were repeated at least three times and a representative result is shown.

RNA isolation and RT-PCR. Total RNA was isolated from cells grown in $\mathrm{LB}$ at $37{ }^{\circ} \mathrm{C}$ to $\mathrm{OD}_{600} 1.2$ as previously described (Amati et al., 2004). RNA template (500 ng) was reverse transcribed using random primers and ThermoScript Reverse Transcriptase (Invitrogen), following the manufacturer's instructions. The resulting cDNA was used as template in PCRs with the following primer pairs: BL517 and BL518 for pgsB, and BL468 and BL469 for veg (Gilman \& Chamberlin, 1983). PCR products were analysed by $1 \%$ agarose gel electrophoresis.

Motility and $\boldsymbol{\gamma}$-PGA production assays. Swimming and swarming assays were performed as already described (Calvio et al., 2008). Motility was scored as positive when cells colonized the entire $8.5 \mathrm{~cm}$ plate in $13 \mathrm{~h}$ at $30{ }^{\circ} \mathrm{C} . \gamma$-PGA production was considered positive only when colonies displayed a mucoid phenotype on LB plates after $16 \mathrm{~h}$ incubation at $37^{\circ} \mathrm{C}$.

$\gamma$-PGA isolation. Cells were grown at $37{ }^{\circ} \mathrm{C}$ with shaking in LB. A $5 \mathrm{ml}$ sample of the culture supernatant was collected at $t_{1}(1 \mathrm{~h}$ after the transition phase) to isolate $\gamma$-PGA as described by Stanley \& Lazazzera (2005), omitting the dialysis step. Roughly $2 \%(\mathrm{v} / \mathrm{v})$ of the recovered $\gamma$-PGA samples were loaded on $6 \%$ acrylamide gels stained with $0.5 \%$ methylene blue in $3 \%$ acetic acid for $30 \mathrm{~min}$ and destained in $\mathrm{H}_{2} \mathrm{O}$.

\section{RESULTS AND DISCUSSION}

\section{Genetic requirements for $\boldsymbol{\gamma}$-PGA production}

$\gamma$-PGA production could be induced in a domestic $B$. subtilis strain (JH642) by transformation with the $\operatorname{deg} Q_{\mathrm{H}}$ and $s w r A A^{+}$alleles (Stanley \& Lazazzera, 2005). Since the $\operatorname{deg} Q_{\mathrm{H}}$ and the $\operatorname{deg} U 32(\mathrm{Hy})$ mutants have similar phenotypes as regards protease production, motility and transformation efficiency (Amory et al., 1987), and taking into account that DegQ enhances DegU phosphorylation (Kobayashi, 2007), we sought to determine if a laboratory strain carrying the $\operatorname{deg} U 32(\mathrm{Hy})$ and the $s w r A A^{+}$alleles could also activate the $p g s$ operon. As expected, the $\operatorname{degU} 32(\mathrm{Hy})$ as well as the $\operatorname{degS200}(\mathrm{Hy})$ mutations were independently able to convert swrAA ${ }^{+}$laboratory strains into $\gamma$-PGA producers (Fig. 1, lanes 1 to 3 ) with a translucent and mucoid colony morphology. $\gamma$-PGA production was dependent on a functional $p g s$ operon, since its disruption eliminated mucoid morphology on LB plates (data not shown). Thus, the $\operatorname{deg} Q_{\mathrm{H}}$ allele can be substituted by an increase in the intracellular levels of DegU P caused by mutations in either DegU or DegS. As shown for $\operatorname{deg} Q_{\mathrm{H}}$ (Stanley \& Lazazzera, 2005), also the $\operatorname{deg} U 32(\mathrm{Hy})$ and $\operatorname{degS200}(\mathrm{Hy})$ mutations activated $\gamma$-PGA production exclusively in $s w r A A^{+}$strains, as isogenic swr $A A^{-}$strains were non-mucoid and $\gamma$-PGA recovery was

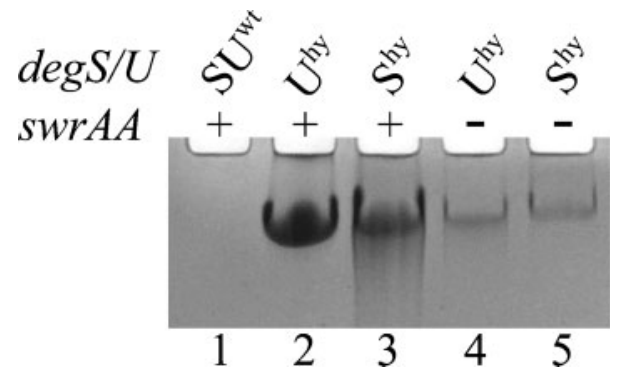

Fig. 1. $\gamma$-PGA production in strains with different genetic backgrounds: electrophoretic separation of $\gamma$-PGA purified from strains with different combinations of the swrAA and degS $U$ alleles. The isogenic strains carry the swrAA gene either in the wt form (+) or with a truncating mutation $(-)$ and the $d e g S / U$ alleles either in the wt form $\left(\mathrm{SU}^{\mathrm{wt}}\right)$ or with the $\operatorname{deg} U 32(\mathrm{Hy})\left(\mathrm{U}^{\mathrm{hy}}\right)$ or the $\operatorname{degS200}(\mathrm{Hy})$ $\left(\mathrm{S}^{\text {hy }}\right)$ mutations, as indicated. The strains are: PB5381 in lane 1, PB5383 in lane 2, PB5390 in lane 3, PB5384 in lane 4 and PB5391 in lane 5. $\gamma$-PGA was purified from the culture supernatant as described in Methods. 
highly compromised (Fig. 1, compare lanes 2 and 4 or 3 and 5).

\section{Cooperativity of DegU P and SwrAA}

To assess the relative contribution of SwrAA and DegU P to the synthesis of $\gamma$-PGA, the expression level of the $p g s$ operon was measured by RT-PCR in four isogenic laboratory strains differing in the status of the swrAA (wt or mutant) and $\operatorname{deg} U$ (wt or Hy) alleles. The expression of $v e g$, a gene constitutively expressed throughout the cell cycle, was used as an internal control (Gilman \& Chamberlin, 1983). In a $\operatorname{deg} U^{+} s w r A A^{-}$genetic background $p g s$ transcripts were not detected and only trace amounts were found in a $\operatorname{deg} U^{+} s w r A A^{+}$strain (Fig. 2a, lanes 2 and 1, respectively). The pgs operon showed limited expression in a $\operatorname{deg} U 32(\mathrm{Hy}) \operatorname{swr} A A^{-}$background; full activation required the presence of both $\operatorname{deg} U 32(\mathrm{Hy})$ and swrAA ${ }^{+}$alleles (Fig. 2a, lanes 4 and 3, respectively).

By using a $p g s B-l a c Z$ translational fusion, transcription of the $p g s$ operon could be measured by $\beta$-galactosidase assay in the different genetic backgrounds (Fig. 2b). There was no production of $\beta$-galactosidase in $\operatorname{deg} U^{+}$strains, irrespective of the swrAA allele present; in a $\operatorname{deg} U 32(\mathrm{Hy})$ swrAA ${ }^{-}$background the pgs-lac $Z$ fusion gave only 58 Miller units, while a fivefold higher activity (309 Miller units) was achieved in a $\operatorname{deg} U 32(\mathrm{Hy}) \mathrm{swrAA^{+ }}$ background, in line with the results obtained by RT-PCR. On the whole, the data shown in Fig. 2 demonstrated that the effect of SwrAA and DegU P is cooperative rather than additive. DegU P alone activated $p g s$ transcription only to a minimal level in the absence of SwrAA (see also lanes 4 and 5 in Fig. 1) while the presence of the sole $s w r A A^{+}$allele (in a $\operatorname{deg} U^{+}$background) had no effect on the $p g s$ operon activation (see also lane 1 in Fig. 1). Moreover, overexpression of SwrAA from an inducible promoter in a $\operatorname{deg} U^{+}$strain did not activate the pgs operon (data not shown). Thus, the contribution of SwrAA is effective only in the presence of high levels of DegU P.

Taken together these data indicate that the activation of the pgs operon is dependent on the co-presence of SwrAA and a high level of DegU P and that the two proteins act synergistically. Cooperativity between SwrAA and DegU has already been observed in motility: SwrAA allows full swimming and swarming exclusively when DegU is present and does not confer any motility advantage if the twocomponent system DegS/U is deleted (Calvio et al., 2008).

\section{Control of swrAA expression and $\gamma$-PGA production}

It had been previously shown that $s w r A A$ transcription is driven by two promoters, a putative $\sigma^{\mathrm{A}}$-dependent promoter $\mathrm{P}_{\text {swrAA(A) }}$ activated by $\operatorname{DegU} \sim \mathrm{P}$, and a $\sigma^{\mathrm{D}}$-dependent promoter $\mathrm{P}_{\text {swraA(D) }}$ (Calvio et al., 2008). Since the $\operatorname{deg} U 32(\mathrm{Hy})$ mutation prevents SigD production by blocking the $\mathrm{P}_{\text {fla/che(A) }}$ (Amati et al., 2004), in a $\operatorname{degU32}(\mathrm{Hy})$ genetic (a) $\operatorname{swrAA}+-+-$ $\operatorname{deg} U$ wt wt hy hy
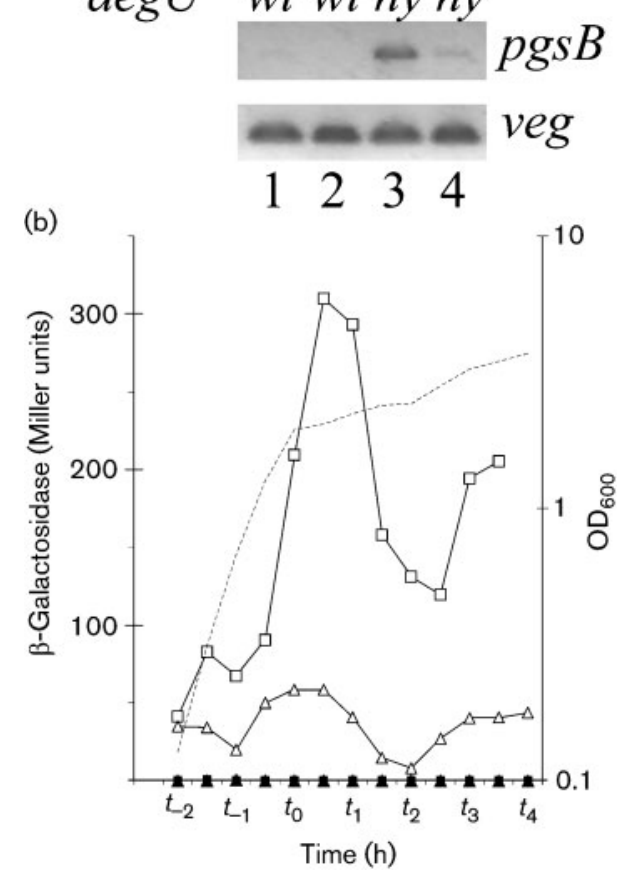

Fig. 2. Expression of the pgs operon in different genetic backgrounds. The expression of the pgs operon in four isogenic strains differing in the status of the $s w r A A$ and $\operatorname{deg} U$ genes was assessed by RT-PCR (a) or by translational fusions to lacZ (b). (a) RT-PCR on total RNA extracted at $t_{1}$ ( $1 \mathrm{~h}$ after the transition phase) from strains grown in LB medium. The ' + ' and ' - ' indicate the wt or mutant swrAA allele, respectively, while the status of $\operatorname{deg} U$ is indicated as ' $w t$ ' or ' $h y$ ' in the case of the $\operatorname{deg} U 32(\mathrm{Hy})$ mutation. Transcripts corresponding to $p g s B$ and veg, as indicated on the right, were amplified with specific primers (see Methods for details). The strains used are: PB5381 (lane 1), PB5382 (lane 2), PB5383 (lane 3) and PB5384 (lane 4). (b) Relative levels of $\beta$ galactosidase (on the left axis) obtained from pgsB-lac $Z$ fusions inserted in the different genetic backgrounds. The dashed line refers to the typical growth curve displayed by these strains, with the $\mathrm{OD}_{600}$ values given on the right axis; $t_{0}$ indicates the transition between the exponential and stationary phases of growth. The strains used are: PB5416 ( $\left.\boldsymbol{\square}, \operatorname{deg} U^{+} \operatorname{swr} A A^{+}\right), \operatorname{PB} 5417(\boldsymbol{\Delta}$, $\left.\operatorname{deg} U^{+} s w r A A^{-}\right), \operatorname{PB} 5418\left(\square, \operatorname{deg} U^{\text {hy }} s w r A A^{+}\right)$and PB5419 $(\triangle$, $\left.\operatorname{deg} U^{\text {hy }} s w r A A^{-}\right)$. Solid symbols are grouped at the baseline.

background only the $\mathrm{P}_{\text {swrAA(A) }}$ is active (Calvio et al., 2008). Indeed, mutations in the swrAA promoters had different outcomes on $\gamma$-PGA production, with deletion of $\mathrm{P}_{\text {swrAA(D) }}$ (Fig. 3, $\mathrm{P}_{\mathrm{D}-}$ in lane 3 ) having a slightly negative effect, but mutation of $\mathrm{P}_{\text {swrAA(A) }}$ critically compromising it (Fig. $3, \mathrm{P}_{\mathrm{A}-}$ in lane 4). As expected, an even stronger reduction of $\gamma$-PGA was obtained when both promoters were mutated (Fig. 3, $\mathrm{P}_{\mathrm{DA}-}$ in lane 5). However, it can be excluded that the role of DegU P is limited to the induction of swrAA expression, since SwrAA overexpression in a $\operatorname{deg} U^{+}$strain had no effect on $\gamma$-PGA production, as reported above. 


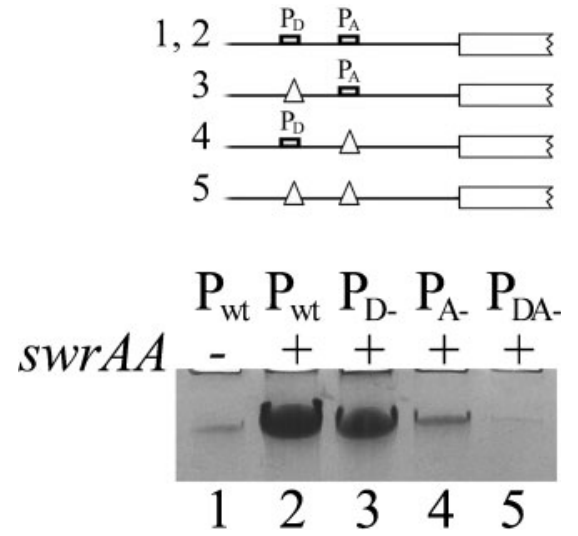

Fig. 3. $\gamma$-PGA production in $P_{s w r A A}$ mutants. Electrophoretic separation of $\gamma$-PGA purified from $\operatorname{deg} U 32(\mathrm{Hy})$ strains carrying the mutant (lane 1, PB5384) or the functional (lanes 2-5) swrAA allele. The functional swrAA allele was expressed from the wt promoter (lane 2, PB5383) or from promoters carrying mutations in the consensus for the binding of SigD (lane 3, PB5439), SigA (lane 4, PB5438) or both (lane 5, PB5440). A schematic representation of the status of the swrAA promoter region present in each strain is given above with the same lane numbering. The symbol ' $\triangle$ ' indicates a deletion.

\section{$\gamma$-PGA activation by SwrAA does not require the expression of the fla/che operon}

The molecular role played by SwrAA is still unclear, although in transcriptional profiling assays SwrAA was found to enhance transcription of the motility and chemotaxis operon fla/che acting on $\mathrm{P}_{\text {fla/che( }}(\mathrm{A})$ (Kearns \& Losick, 2005). If this was the exclusive role played by SwrAA, then a gene(s) belonging to the fla/che operon including sigD, or a $\sigma^{\mathrm{D}}$-dependent gene, had to be responsible for $\gamma$-PGA production. As the fla/che operon is switched off in a $\operatorname{deg} U 32(\mathrm{Hy})$ background (Amati et al., 2004; Calvio et al., 2008) this hypothesis is unlikely, unless the candidate gene(s) can escape $\operatorname{deg} U 32(\mathrm{Hy})$ repression. This occurrence was ruled out by the following two sets of experiments: either perturbing the fla/che operon in $\operatorname{degU} 32(\mathrm{Hy}) \operatorname{swrAA} A^{+}$strains or, conversely, maintaining the fla/che transcription in a $\operatorname{deg} U 32(\mathrm{Hy})$ swrA $A^{-}$background. Results from these experiments are summarized in Table 3. In the first instance, a sigD null mutation (Calvio et al., 2008) or a $21 \mathrm{~kb}$ deletion in the fla/che operon $(\triangle$ flaA, Barilla et al., 1994) did not affect $\gamma$-PGA production in a $\operatorname{deg} U 32(\mathrm{Hy}) \operatorname{swr} A A^{+}$background. In the second instance, the effect of the dhsA6 mutation (Amati et al., 2004), a $\mathrm{P}_{\text {fla/che(A) }}$ up-mutation, was analysed in a

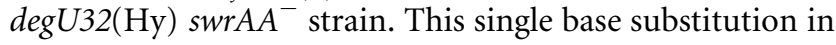
$\mathrm{P}_{\text {fla/che(A) }}$ allowed swarming and full swimming motilities in the absence of SwrAA but did not confer on this strain the ability to produce $\gamma$-PGA. Not even overexpression of SigD from an inducible promoter was sufficient for $\gamma$-PGA production in a $\operatorname{deg} U 32(\mathrm{Hy}) \operatorname{swr} A A^{-}$strain. Indeed, SigD
Table 3. $\gamma$-PGA production and motility in different $\operatorname{deg} \mathrm{U} 32(\mathrm{Hy})$ strains

\begin{tabular}{|c|c|c|c|c|c|}
\hline \multirow[t]{2}{*}{ Strain } & \multicolumn{3}{|c|}{ Relevant genotype } & \multicolumn{2}{|c|}{ Phenotype $^{\star}$} \\
\hline & swrAA & fla/che & $\operatorname{sig} D$ & Motility & $\gamma$-PGA \\
\hline PB5383 & wt & wt & wt & $\mathrm{N}$ & $\mathrm{Y}$ \\
\hline PB5384 & - & wt & wt & $\mathrm{N}$ & $\mathrm{N}$ \\
\hline PB5429 & wt & wt & $\Delta \dagger$ & $\mathrm{N}$ & $\mathrm{Y}$ \\
\hline PB5422 & wt & $\Delta \dagger$ & wt & $\mathrm{N}$ & Y \\
\hline PB5384 pSigD & - & wt & $(+++) \neq$ & $\mathrm{N}$ & $\mathrm{N}$ \\
\hline PB5447 & - & dhsA6§ & wt & Y & $\mathrm{N}$ \\
\hline
\end{tabular}

*The motility and $\gamma$-PGA phenotypes are referred to the ability to swarm and fully swim on appropriate media (Calvio et al., 2008) and to display a mucoid colony morphology, as described in Methods. ' $\mathrm{Y}$ ' represents full capacity and ' $\mathrm{N}$ ' indicates the lack of the phenotype. $\dagger$ The $\Delta$ symbol indicates that the locus was replaced by a resistance marker.

$\ddagger$ SigD was present on a multicopy plasmid (Barilla et al., 1994) and was overexpressed from an IPTG-inducible promoter.

$\S \mathrm{P}_{\text {fla/che }}(\mathrm{A})$ carries an up-mutation that allows it to escape the $\operatorname{deg} U 32(\mathrm{Hy})$ repression (Amati et al., 2004) and to become independent of $s w r A A$ for full activation.

overexpression represses transcription of the $\gamma$-PGA biosynthetic genes $p g s B, C, A A$ while it activates $y w t D$ (Kearns \& Losick, 2005), the gene coding for PgdS, an enzyme involved in $\gamma$-PGA degradation (Suzuki \& Tahara, 2003). This is additional evidence that SwrAA must activate $\gamma$-PGA synthesis through a pathway different from the one acting on the fla/che operon.

\section{Concluding remarks}

This study has shown that the role played by SwrAA in $p g s$ operon expression is independent of its action on $\mathrm{P}_{\text {fla/che }(\mathrm{A})}$ and therefore the role of DegU32(Hy) and SwrAA in $\gamma$-PGA production is independent of their effect on motility.

Activation of DegU and of a second transcriptional regulator such as Spo0A has been recently found to be required for the expression of $a p r E, y v c A$ and $y v a B$ in $B$. subtilis (Veening et al., 2008a; Verhamme et al., 2009) and such a dual regulation has been described as a logic AND gate (Veening et al., 2008b). Although it would be tempting to add the $p g s$ operon to the list of genes regulated by AND gate systems, the lack of phenotypes produced by SwrAA alone (in the absence of $\mathrm{Deg} \mathrm{U} \sim \mathrm{P}$ ) rules out the existence of two independent regulators, as required by this logic circuitry. The data presented here and elsewhere (Calvio et al., 2008) support a model in which SwrAA interacts with DegU P, thereby enhancing/modifying its properties, although currently there is no evidence supporting a physical contact between the two proteins. 


\section{ACKNOWLEDGEMENTS}

This work was supported by the Italian 'Ministero dell'Istruzione, dell'Università e della Ricerca' (grant PRIN2005 \#2005058814) and by an INGENIO fellowship from 'Regione Lombardia' to A. G. We are grateful to E. Andreoli for invaluable technical help, and to Professor A. Torroni for reading the manuscript.

\section{REFERENCES}

Amati, G., Bisicchia, P. \& Galizzi, A. (2004). DegU-P represses expression of the motility fla-che operon in Bacillus subtilis. J Bacteriol 186, 6003-6014.

Amory, A., Kunst, F., Aubert, E., Klier, A. \& Rapoport, G. (1987). Characterization of the sacQ genes from Bacillus licheniformis and Bacillus subtilis. J Bacteriol 169, 324-333.

Arnaud, M., Chastanet, A. \& Débarbouillé, M. (2004). New vector for efficient allelic replacement in naturally nontransformable, low-GCcontent, gram-positive bacteria. Appl Environ Microbiol 70, 68876891

Barilla, D., Caramori, T. \& Galizzi, A. (1994). Coupling of flagellin gene transcription to flagellar assembly in Bacillus subtilis. J Bacteriol 176, 4558-4564.

Calvio, C., Celandroni, F., Ghelardi, E., Amati, G., Salvetti, S., Ceciliani, F., Galizzi, A. \& Senesi, S. (2005). Swarming differentiation and swimming motility in Bacillus subtilis are controlled by swrA, a newly identified dicistronic operon. J Bacteriol 187, 5356-5366.

Calvio, C., Osera, C., Amati, G. \& Galizzi, A. (2008). Autoregulation of swrAA and motility in Bacillus subtilis. J Bacteriol 190, 5720-5728.

Candela, T. \& Fouet, A. (2006). Poly-gamma-glutamate in bacteria. Mol Microbiol 60, 1091-1098.

Dahl, M. K., Msadek, T., Kunst, F. \& Rapoport, G. (1992). The phosphorylation state of the DegU response regulator acts as a molecular switch allowing either degradative enzyme synthesis or expression of genetic competence in Bacillus subtilis. J Biol Chem 267, 14509-14514.

Gilman, M. Z. \& Chamberlin, M. J. (1983). Developmental and genetic regulation of Bacillus subtilis genes transcribed by $\sigma^{28}$-RNA polymerase. Cell 35, 285-293.

Kearns, D. B. \& Losick, R. (2005). Cell population heterogeneity during growth of Bacillus subtilis. Genes Dev 19, 3083-3094.

Kearns, D. B., Chu, F., Rudner, R. \& Losick, R. (2004). Genes governing swarming in Bacillus subtilis and evidence for a phase variation mechanism controlling surface motility. Mol Microbiol 52, $357-369$.
Kobayashi, K. (2007). Gradual activation of the response regulator $\mathrm{DegU}$ controls serial expression of genes for flagellum formation and biofilm formation in Bacillus subtilis. Mol Microbiol 66, 395-409.

Miller, J. H. (1972). Experiments in Molecular Genetics. Cold Spring Harbor, NY: Cold Spring Harbor Laboratory.

Msadek, T., Kunst, F., Henner, D., Klier, A., Rapoport, G. \& Dedonder, R. (1990). Signal transduction pathway controlling synthesis of a class of degradative enzymes in Bacillus subtilis: expression of the regulatory genes and analysis of mutations in $\operatorname{deg} S$ and degU. J Bacteriol 172, 824-834.

Schumann, W., Ehrlich, S. D. \& Ogasawara, N. (2001). Functional Analysis of Bacterial Genes: a Practical Manual. Chichester: Wiley.

Shih, I.-L. \& Van, Y.-T. (2001). The production of poly-(gammaglutamic acid) from microorganisms and its various applications. Bioresour Technol 79, 207-225.

Stanley, N. R. \& Lazazzera, B. A. (2005). Defining the genetic differences between wild and domestic strains of Bacillus subtilis that affect poly- $\gamma$-DL-glutamic acid production and biofilm formation. $\mathrm{Mol}$ Microbiol 57, 1143-1158.

Suzuki, T. \& Tahara, Y. (2003). Characterization of the Bacillus subtilis $y w t D$ gene, whose product is involved in $\gamma$-polyglutamic acid degradation. J Bacteriol 185, 2379-2382.

Tanaka, T., Kawata, M. \& Mukai, K. (1991). Altered phosphorylation of Bacillus subtilis DegU caused by single amino acid changes in DegS. J Bacteriol 173, 5507-5515.

Urushibata, Y., Tokuyama, S. \& Tahara, Y. (2002). Difference in transcription levels of cap genes for $\gamma$-polyglutamic acid production between Bacillus subtilis IFO 16449 and Marburg 168. J Biosci Bioeng 93, 252-254.

Veening, J. W., Igoshin, O. A., Eijlander, R. T., Nijland, R., Hamoen, L. W. \& Kuipers, O. P. (2008a). Transient heterogeneity in extracellular protease production by Bacillus subtilis. Mol Syst Biol 4, 184.

Veening, J. W., Smits, W. K. \& Kuipers, O. P. (2008b). Bistability, epigenetics, and bet-hedging in bacteria. Annu Rev Microbiol 62, 193210.

Verhamme, D. T., Kiley, T. B. \& Stanley-Wall, N. R. (2007). DegU coordinates multicellular behaviour exhibited by Bacillus subtilis. Mol Microbiol 65, 554-568.

Verhamme, D. T., Murray, E. J. \& Stanley-Wall, N. R. (2009). DegU and Spo0A jointly control transcription of two loci required for complex colony development by Bacillus subtilis. J Bacteriol 191, 100108.

Yang, M., Ferrari, E., Chen, E. \& Henner, D. J. (1986). Identification of the pleiotropic sacQ gene of Bacillus subtilis. J Bacteriol 166, 113-119.

Edited by: T. Abee 